\title{
Effect of Foliar Application of Micronutrients on Growth and Flowering of Floribunda Rose under Open Condition
}

\author{
S. Poornima ${ }^{1 *}$, P.M. Munikrishnappa ${ }^{1}$, S. Anil Kumar², \\ G.K. Seetharamu ${ }^{1}$ and Rajiv Kumar ${ }^{1}$ \\ ${ }^{1}$ Department of Floriculture and Landscape Architecture, ${ }^{2}$ Department of Soil Science, \\ College of Horticulture, Bengaluru, University of Horticultural Sciences, \\ Bagalkot 587 102, Karnataka, India \\ *Corresponding author
}

\section{A B S T R A C T}

\section{Keywords}

Rose, Micronutrients, Foliar spray, Growth and quality

\section{Article Info}

Accepted: 15 September 2018 Available Online: 10 October 2018
An experiment was carried out at College of Horticulture, UHS campus, Bengaluru during 2016-17. The experiment was laid out in a Randomized Complete Block Design (RCBD) comprising of eight treatments and three replications. Treatment detail includes micronutrients viz., $\mathrm{MgSO}_{4}, \mathrm{MnSO}_{4}, \mathrm{FeSO}_{4}$, Boron, $\mathrm{ZnSO}_{4}$ and $\mathrm{CuSO}_{4}$ at different levels on growth, yield and quality of floribunda rose cv. Mirabalis. Results revealed that foliar application of $\mathrm{T}_{7}-\mathrm{ZnSO}_{4}(0.75 \%)+$ Boric acid $(0.5 \%)+\mathrm{FeSO}_{4}(1.5 \%)+\mathrm{MgSO}_{4}(0.5 \%)+$ $\mathrm{MnSO}_{4}(1 \%)+\mathrm{CuSO}_{4}(0.3 \%)$ at 210 days after pruning. Results revealed that increased in plant height $(73.61 \mathrm{~cm})$, plant spread $(\mathrm{N}-\mathrm{S}$ direction) $(64.00 \mathrm{~cm})$, E-W direction $(50.32$ $\mathrm{cm})$, number of shoots per plant (14.83), shoot length $(61.27 \mathrm{~cm})$, leaf chlorophyll content (51.22), more leaf area $\left(3.61 \mathrm{~cm}^{2}\right)$. Among flowering, yield and quality parameters, early bud initiation (28.60), early first flowering (37.58), flower diameter $(4.23 \mathrm{~cm})$, number of petals per flower (32.40), number of flowers per plant (116.98) and total yield per plant $(0.73 \mathrm{~kg})$. However it was minimum in control.

\section{Introduction}

Rose is one of the natures beautiful creations and is universally acclaimed as the Queen of flowers. It is the most beautiful among all the flowers with variety of shapes, sizes, colors and versatility.

Roses are grown in the wide range of soil and climatic conditions and suitable for garden decoration and landscaping.
Floribunda roses possess the character of producing flowers in cluster and few varieties of floribunda are highly suitable for garland preparation, poojas and other social functions.

Rose var. Mirabalis, belongs to the floribunda group which is stiff shrub, smaller and bushier than the average hybrid tea but less dense and sprawling than the average polyantha. Flowers are red in color known for producing better shaped flowers in cluster for a longer period. 
Rose is an extensive feeder of nutrient and about 17 elements have been known to play important role for its proper growth and development. Foliar application of nutrients has become popular in recent times.

It is an excellent supplement to root feeding, where the leaves can directly absorb the nutrients. This is an effective method and helps in producing healthy and abundant foliage and flowers (Zieslin and Halevy, 1972 and Zieslin et al., 1973).

Hence keeping in view the importance of the effect of foliar application of micronutrient on plant growth, flower yield and flower quality, the present investigation was carried out to know the effect of foliar application of micronutrients on growth, flowering, quality and yield of floribunda rose cv. Mirabalis under open condition

\section{Materials and Methods}

The experiment entitled "Effect of foliar application of micronutrients on growth, yield and quality of floribunda rose cv. Mirabalis"'was conducted at College of Horticulture, University of Horticultural Sciences Campus, GKVK, Bengaluru during 2016-2017. The spacing $1 \mathrm{~m} \times 0.45 \mathrm{~m}$ and the experiment was laid out in Randomized Blok Design with eight treatments includes, viz., $\mathrm{T}_{0}$ (Control) - RDF (NPK-10:10:15 g/plant, 2 split doses $)+$ FYM (2 kg/plant), $\mathrm{T}_{1}$-Farmers practice - Boric acid $(0.5 \%)+\mathrm{MgSO}_{4}(0.75 \%)$ $+\mathrm{ZnSO}_{4}-(0.75 \%), \quad \mathrm{T}_{2}$-Rose mixture (commercially available in market) Flower booster - $\mathrm{ZnSO}_{4}(3 \%)+$ Boric acid $(0.5 \%)+$ $\mathrm{FeSO}_{4}(0.5 \%)+\mathrm{MnSO}_{4}(0.2 \%), \mathrm{T}_{3}$-Boric acid $(0.25 \%)+\mathrm{ZnSO}_{4}(0.75 \%), \mathrm{T}_{4}-\mathrm{ZnSO}_{4}(0.75 \%)$ + Boric acid $(0.5 \%)+\mathrm{FeSO}_{4}(1.5 \%) \mathrm{T}_{5}-$ $\mathrm{ZnSO}_{4}(0.75 \%)+$ Boric acid $(0.5 \%)+\mathrm{FeSO}_{4}$ $(1.5 \%)+\mathrm{MgSO}_{4}(0.5 \%), \mathrm{T}_{6}-\mathrm{ZnSO}_{4}(0.75 \%)$ + Boric acid $(0.5 \%)+\mathrm{FeSO}_{4}(1.5 \%)+\mathrm{MgSO}_{4}$ $(0.5 \%)+\mathrm{MnSO}_{4}(1 \%) \mathrm{T}_{7}-\mathrm{ZnSO}_{4}(0.75 \%)+$
Boric acid $(0.5 \%)+\mathrm{FeSO}_{4}(1.5 \%)+\mathrm{MgSO}_{4}$ $(0.5 \%)+\mathrm{MnSO}_{4}(1 \%)+\mathrm{CuSO}_{4}(0.3 \%)$. Already established plants of rose cv. Mirabalis were used for conducting the experiment. The micronutrients were applied as per the proposed treatments at 15 days interval starting from 30 days after pruning to 210 days. Data regarding different growth parameters as plant height $(\mathrm{cm})$, plant spread (cm), number of shoots per plant, shoot length $(\mathrm{cm})$, leaf area $\left(\mathrm{cm}^{2}\right)$, and chlorophyll content were recorded at 30 days interval up to 210 days.

\section{Results and Discussion}

\section{Effect of foliar application of micronutrients on growth}

Micronutrients had effect on growth of rose $\mathrm{cv}$. Mirabalis is evident from the results. At 210 days after pruning maximum plant height $(73.61 \mathrm{~cm})$ was registered in treatment $\mathrm{T}_{7-}$ $\mathrm{ZnSO}_{4}(0.75 \%)+$ Boric acid $(0.5 \%)+\mathrm{FeSO}_{4}$ $(1.5 \%)+\mathrm{MgSO}_{4}(0.5 \%)+\mathrm{MnSO}_{4}(1 \%)+$ $\mathrm{CuSO}_{4}(0.3 \%)$ and it was on par with $\mathrm{T}_{2}-$ $\mathrm{ZnSO}_{4}(3 \%)+$ Boric acid $(0.5 \%)+\mathrm{FeSO}_{4}$ $(0.5 \%)+\mathrm{MnSO}_{4}(0.2 \%)(70.16 \mathrm{~cm})$ and $\mathrm{T}_{6}-$ $\mathrm{ZnSO}_{4}(0.75 \%)+$ Boric acid $(0.5 \%)+\mathrm{FeSO}_{4}$ $(1.5 \%)+\mathrm{MgSO}_{4}(0.5 \%)+\mathrm{MnSO}_{4}(1 \%)$ $(70.89 \mathrm{~cm})$ and it was recorded minimum $(60.99 \mathrm{~cm})$ in treatment control $\left(\mathrm{T}_{0}\right)$. Increase in the plant height due to combination of micronutrients indicates the synergistic effect of the all micronutrients. Iron, being essential component of several dehydrogenase, protenase, peptidase and promotes growth hormones and closely associated with growth. Whereas, maximum east to west plant spread $50.32 \mathrm{~cm}$ and north to south plant spread $(64 \mathrm{~cm})$ was recorded in $\mathrm{T}_{7-} \mathrm{ZnSO}_{4}(0.75 \%)+$ Boric acid $(0.5 \%)+\mathrm{FeSO}_{4}(1.5 \%)+\mathrm{MgSO}_{4}$ $(0.5 \%)+\mathrm{MnSO}_{4}(1 \%)+\mathrm{CuSO}_{4}(0.3 \%)$ whereas, lowest $(37.20 \mathrm{~cm})(50.61 \mathrm{~cm})$ in control $\left(\mathrm{T}_{0}\right)$ respectively. Increase in the plant spread might be due to copper involvement in 
numerous physiological processes and is an essential co factor for many metallo proteins (Kode et al., 2015). Maximum number of shoots $(14.83)$, shoot length $(61.27 \mathrm{~cm})$, leaf area $\left(3.62 \mathrm{~cm}^{2}\right)$ was recorded in $\mathrm{T}_{7^{-}} \mathrm{ZnSO}_{4}$ $(0.75 \%)+$ Boric acid $(0.5 \%)+\mathrm{FeSO}_{4}(1.5 \%)$ $+\mathrm{MgSO}_{4}(0.5 \%)+\mathrm{MnSO}_{4}(1 \%)+\mathrm{CuSO}_{4}$ $(0.3 \%)$ whereas, lowest $(13.77)(48.83 \mathrm{~cm})$ $\left(3.04 \mathrm{~cm}^{2}\right)$ respectively. This might be due to zinc involves in the synthesis of auxin IAA and for carbohydrate metabolism, protein synthesis and also photosynthetic reactions were accelerated in the presence of zinc, boron and copper (Almas et al., 2014; Ali et al., 2013).

Effect of foliar application of micronutrients on flowering, quality and yield

Number of days taken to first bud appearance(28.27 days) and early emergence of flower (36.35 days) was recorded in treatment $\mathrm{T}_{3}-$ Boric acid $(0.25 \%)+\mathrm{ZnSO}_{4}$ $(0.75 \%)$ followed by $\mathrm{T}_{7}-\mathrm{ZnSO}_{4}(0.75 \%)+$ Boric acid $(0.5 \%)+\mathrm{FeSO}_{4}(1.5 \%)+\mathrm{MgSO}_{4}$ $(0.5 \%)+\mathrm{MnSO}_{4}(1 \%)+\mathrm{CuSO}_{4}(0.3 \%)(28.60$ days)(37.58 days) respectively. However, maximum number of days taken for flower bud initiation (31.43 days), Early flowering rose cv. Mirabalis might be due to boric acid role in translocation of sugars, starches, phosphorus etc. might have utilized for better development of bud size and early flower bud opening and also iron involves in synthesis of plant hormones during flower opening stage.

Maximum flower diameter $(4.23 \mathrm{~cm})$ was recorded in treatment $\mathrm{T}_{7}-\mathrm{ZnSO}_{4}(0.75 \%)+$ Boric acid $(0.5 \%)+\mathrm{FeSO}_{4}(1.5 \%)+\mathrm{MgSO}_{4}$ $(0.5 \%)+\mathrm{MnSO}_{4}(1 \%)+\mathrm{CuSO}_{4}(0.3 \%)$ while, it was minimum $(3.66 \mathrm{~cm})$ in control $\left(\mathrm{T}_{0}\right)$ (Patel et al., 2016). Increase in the flower diameter might be due to iron stimulating metabolic activity, with the stimulating effect on cell wall loosing, results on cell elongation along with cell enlargement, it results in enlarging flower and stem diameters and chelated mix micronutrients increases the flower diameter (Almas et al., 2014). The maximum number of petals (32.40) per flower was recorded in $\mathrm{T}_{7}-\mathrm{ZnSO}_{4}(0.75 \%)+$ Boric acid $(0.5 \%)+\mathrm{FeSO}_{4}(1.5 \%)+\mathrm{MgSO}_{4}(0.5 \%)$ $+\mathrm{MnSO}_{4}(1 \%)+\mathrm{CuSO}_{4}(0.3 \%)$ which was followed by treatment $\mathrm{T}_{2}-\mathrm{ZnSO}_{4}(3 \%)+$ Boric acid $(0.5 \%)+\mathrm{FeSO}_{4}(0.5 \%)+\mathrm{MnSO}_{4}$ $(0.2 \%)$ was recorded 32.07 petals per flower. The minimum number of petals (31.23) per flower was recorded in control $\left(\mathrm{T}_{0}\right)$. Increased number of petals per flower might be due to optimum concentration of elements, enhance the plant growth and involves in cellular processes (i.e. photosynthesis, electron transport, etc.) (Kode et al., 2015). Maximum number of flowers (116.98) per plant was recorded in treatment $\mathrm{T}_{7-} \mathrm{ZnSO}_{4}(0.75 \%)+$ Boric acid $(0.5 \%)+\mathrm{FeSO}_{4}(1.5 \%)+\mathrm{MgSO}_{4}$ $(0.5 \%)+\mathrm{MnSO}_{4}(1 \%)+\mathrm{CuSO}_{4}(0.3 \%)$. The lowest number of flowers per plant (81.17) was recorded in control $\left(\mathrm{T}_{0}\right)$ at 210 days after pruning. Increase the flower number due to higher number of shoots per plant. $\mathrm{MgSO}_{4}$ with all other nutrients influenced the number of flowers positively; the synergistic effect is high with boric acid, followed by $\mathrm{FeSO}_{4}$ and $\mathrm{ZnSO}_{4}$. Among the treatments, $\mathrm{T}_{7-} \mathrm{ZnSO}_{4}$ $(0.75 \%)+$ Boric acid $(0.5 \%)+\mathrm{FeSO}_{4}(1.5 \%)$ $+\mathrm{MgSO}_{4}(0.5 \%)+\mathrm{MnSO}_{4}(1 \%)+\mathrm{CuSO}_{4}$ $(0.3 \%)$ was recorded highest flower yield $(0.73 \mathrm{~kg})$ per plant followed by $\mathrm{T}_{6}-\mathrm{ZnSO}_{4}$ $(0.75 \%)+$ Boric acid $(0.5 \%)+\mathrm{FeSO}_{4}(1.5 \%)$ $+\mathrm{MgSO}_{4}(0.5 \%)+\mathrm{MnSO}_{4}(1 \%)(0.70 \mathrm{~kg})$ per plant. However, the minimum of $0.54 \mathrm{~kg}$ flower yield per plant was recorded in control $\left(\mathrm{T}_{0}\right)$. This may be due to increased vegetative characters, like plant height, more number of shoots and plant spread which helps in production of more photosynthesis resulting in greater accumulation of dry matter which in turn directly or indirectly lead to the production of more number of flowers per plant (Jagtap et al., 2012) (Table 1 and 2). 


\section{Int.J.Curr.Microbiol.App.Sci (2018) 7(10): 1873-1878}

Table.1 Effect of foliar application of micronutrients on growth of rose cv. Mirabalis after 210 days of prunning

\begin{tabular}{|c|c|c|c|c|c|c|c|}
\hline Treatments & $\begin{array}{l}\text { Plant height } \\
\text { (cm) }\end{array}$ & $\begin{array}{l}\text { North to South } \\
\text { plant spread } \\
(\mathrm{cm})\end{array}$ & $\begin{array}{l}\text { East to West } \\
\text { plant spread } \\
(\mathrm{cm})\end{array}$ & $\begin{array}{l}\text { Number of } \\
\text { shoots per } \\
\text { plant }\end{array}$ & $\begin{array}{l}\text { Shoot length } \\
\text { (cm) }\end{array}$ & $\begin{array}{l}\text { Chlorophyll } \\
\text { content }\end{array}$ & Leaf area $\left(\mathrm{cm}^{2}\right)$ \\
\hline $\mathbf{T}_{1}$ & 63.14 & 54.28 & 38.24 & 14.00 & 50.06 & 46.20 & 3.20 \\
\hline $\mathbf{T}_{2}$ & 70.16 & 62.35 & 49.56 & 14.17 & 60.86 & 46.03 & 3.30 \\
\hline $\mathbf{T}_{\mathbf{3}}$ & 66.28 & 55.29 & 41.23 & 13.83 & 51.20 & 46.98 & 3.41 \\
\hline $\mathbf{T}_{4}$ & 67.94 & 58.42 & 44.21 & 14.13 & 56.02 & 50.12 & 3.44 \\
\hline $\mathbf{T}_{5}$ & 69.05 & 58.53 & 45.17 & 14.50 & 53.54 & 51.25 & 3.47 \\
\hline $\mathrm{T}_{6}$ & 70.89 & 63.59 & 48.92 & 14.63 & 60.05 & 50.45 & 3.51 \\
\hline $\mathbf{T}_{7}$ & 73.61 & 64.00 & 50.32 & 14.83 & 61.27 & 51.22 & 3.61 \\
\hline $\mathbf{T}_{\mathbf{0}}$ & 60.99 & 50.61 & 37.20 & 13.77 & 48.83 & 45.16 & 3.04 \\
\hline S. E.m \pm & 1.86 & 2.13 & 1.05 & 0.14 & 2.02 & 0.08 & 0.07 \\
\hline CD at $5 \%$ & 4.42 & 6.39 & 5.10 & NS & 5.23 & NS & 0.14 \\
\hline $\mathrm{CV}(\%)$ & 9.06 & 7.42 & 7.23 & 4.95 & 9.58 & 5.73 & 7.45 \\
\hline
\end{tabular}

$\mathrm{T}_{0^{-}}$Control; $\mathrm{T}_{1^{-}}$Farmers practice - Boric acid $(0.5 \%)+\mathrm{MgSO}_{4}(0.75 \%)+\mathrm{ZnSO}_{4}-(0.75 \%)$

$\mathrm{T}_{2}$ - Rose mixture, Flower booster $-\mathrm{ZnSO}_{4}(3 \%)+$ Boric acid $(0.5 \%)+\mathrm{FeSO}_{4}(0.5 \%)+\mathrm{MnSO}_{4}(0.2 \%)$

$\mathrm{T}_{3}$ - Boric acid $(0.25 \%)+\mathrm{ZnSO}_{4}(0.75 \%) ; \mathrm{T}_{4}-\mathrm{ZnSO}_{4}(0.75 \%)+$ Boric acid $(0.5 \%)+\mathrm{FeSO}_{4}(1.5 \%)$

$\mathrm{T}_{5}-\mathrm{T}_{4}+\mathrm{MgSO}_{4}(0.5 \%) ; \mathrm{T}_{6}-\mathrm{T}_{5}+\mathrm{MnSO}_{4}(1 \%) ; \mathrm{T}_{7^{-}} \mathrm{T}_{6}+\mathrm{CuSO}_{4}(0.3 \%) ; \mathrm{NS}-$ Non Significant

DAP - Days after pruning 


\section{Int.J.Curr.Microbiol.App.Sci (2018) 7(10): 1873-1878}

Table.2 Effect of foliar application of micronutrients on flowering and quality of rose cv. Mirabalis after 210 days of pruning

\begin{tabular}{|c|c|c|c|c|c|c|}
\hline Treatments & $\begin{array}{l}\text { Days to bud } \\
\text { initiation }\end{array}$ & $\begin{array}{l}\text { Days to first } \\
\text { flowering }\end{array}$ & $\begin{array}{c}\text { Flower } \\
\text { diameter }(\mathrm{cm})\end{array}$ & $\begin{array}{l}\text { Number of } \\
\text { petals per } \\
\text { flower }\end{array}$ & $\begin{array}{l}\text { Number of } \\
\text { flower per } \\
\text { plant }\end{array}$ & $\begin{array}{c}\text { Total flower } \\
\text { yield per plant } \\
\text { (kg) }\end{array}$ \\
\hline $\mathbf{T}_{1}$ & 30.07 & 43.03 & 3.94 & 31.73 & 91.17 & 0.56 \\
\hline $\mathbf{T}_{2}$ & 28.73 & 38.53 & 3.84 & 32.07 & 86.57 & 0.55 \\
\hline $\mathbf{T}_{3}$ & 28.27 & 36.35 & 3.94 & 31.43 & 89.14 & 0.57 \\
\hline $\mathbf{T}_{4}$ & 28.87 & 39.89 & 3.97 & 31.53 & 90.98 & 0.58 \\
\hline $\mathbf{T}_{5}$ & 29.63 & 41.67 & 3.99 & 31.70 & 93.93 & 0.62 \\
\hline $\mathbf{T}_{6}$ & 29.10 & 40.98 & 4.07 & 31.90 & 112.40 & 0.70 \\
\hline $\mathbf{T}_{7}$ & 28.60 & 37.58 & 4.23 & 32.40 & 116.98 & 0.73 \\
\hline $\mathrm{T}_{\mathbf{0}}$ & 31.43 & 43.87 & 3.66 & 31.23 & 81.17 & 0.54 \\
\hline S. E.m & 0.09 & 0.06 & 0.12 & 0.14 & 2.24 & 0.03 \\
\hline $\mathrm{CD}$ at $5 \%$ & 0.27 & 0.18 & 0.19 & NS & 8.81 & 0.10 \\
\hline $\mathrm{CV}(\%)$ & 7.79 & 6.68 & 7.28 & 6.12 & 6.82 & 9.01 \\
\hline
\end{tabular}

$\mathrm{T}_{0^{-}}$Control; $\mathrm{T}_{1}$ - Farmers practice - Boric acid $(0.5 \%)+\mathrm{MgSO}_{4}(0.75 \%)+\mathrm{ZnSO}_{4}-(0.75 \%)$

$\mathrm{T}_{2}$ - Rose mixture, Flower booster $-\mathrm{ZnSO}_{4}(3 \%)+$ Boric acid $(0.5 \%)+\mathrm{FeSO}_{4}(0.5 \%)+\mathrm{MnSO}_{4}(0.2 \%)$

$\mathrm{T}_{3}$ - Boric acid $(0.25 \%)+\mathrm{ZnSO}_{4}(0.75 \%) ; \mathrm{T}_{4}-\mathrm{ZnSO}_{4}(0.75 \%)+$ Boric acid $(0.5 \%)+\mathrm{FeSO}_{4}(1.5 \%)$

$\mathrm{T}_{5}-\mathrm{T}_{4}+\mathrm{MgSO}_{4}(0.5 \%) ; \mathrm{T}_{6}-\mathrm{T}_{5}+\mathrm{MnSO}_{4}(1 \%) ; \mathrm{T}_{7}-\mathrm{T}_{6}+\mathrm{CuSO}_{4}(0.3 \%)$ 
The present investigation reveals that there was an improvement in the growth, yield and quality parameters of floribunda rose with different micronutrients combination. Based on the results, it concluded that treatment $\mathrm{T}_{7-}$ $\mathrm{ZnSO}_{4}(0.75 \%)+$ Boric acid $(0.5 \%)+\mathrm{FeSO}_{4}$ $(1.5 \%)+\mathrm{MgSO}_{4}(0.5 \%)+\mathrm{MnSO}_{4}(1 \%)+$ $\mathrm{CuSO}_{4}(0.3 \%)$ produced maximum plant height, plant spread, minimum days taken for flowering and total yield per plant.

\section{References}

Ali, B., Ahmad, R. and Bohloul, A., 2012, The effect of iron chelate foliar application on damask rose. Ann. Biol. Res., 4 (4): 53-55.

Almas, Barad, A. V. and Madhuri, G., 2014, Effect of different levels of pruning and micronutrient $(\mathrm{Fe})$ on growth, flowering and cut flower yield of Dutch rose (Rosa hybrid Linn.) cv. First red under greenhouse condition. Asian J. Hort., 9(2): 291-296.
Jagtap, H. D., Golliwar, V. J. and Thakre, S. A., 2012, Effect of foliar application of micronutrients on growth and flowering of rose under poly house conditions. Asian J. Hort., 7(1): 25-27.

Kode, S. K., Reddy, A. S., Pratap, M., Rao, P. V. and Raju, B. G., 2015, Effect of different micronutrients sprays on growth, flower yield and vase life of Rose Cv. Sophia Loren. NASS., 33(2): 206- 230.

Patel, H., Bhatt, D., Patel, G. D., Chawla, S. L., and Gurjar, T., 2016, Effect of foliar application of micronutrients on growth and flowering of Rose cv. Top Secret under poly house condition. Intl. J. Life. Sci. 11(1): 603-606.

Zieslin, N. and Halevy, A. H., 1972, The role of $\mathrm{CO}_{2}$ in increasing the yield of 'Baccara' roses. J. Hort. Res., 12: 97100.

Zieslin, N., Halevy, A. H. and Biran, I., 1973, Sources of variability in greenhouse rose flower production. J. Am. Soc. Hort. Sci., 98: 321-324.

\section{How to cite this article:}

Poornima, S., P.M. Munikrishnappa, S. Anil Kumar, G.K. Seetharamu and Rajiv Kumar. 2018. Effect of Foliar Application of Micronutrients on Growth and Flowering of Floribunda Rose under Open Condition. Int.J.Curr.Microbiol.App.Sci. 7(10): 1873-1878.

doi: https://doi.org/10.20546/ijcmas.2018.710.215 